\title{
THE CHARACTER DEVELOPMENT OF 'BEN' IN GIFTED HANDS: THE BEN CARSON'S STORY THROUGH ERIKSON'S PSYCHOSOCIAL THEORY
}

\author{
Cicilia Angelis AGM, Ira Miranti, Nina Dwiastuty
}

cicilia.angelis@gmail.com

Universitas Indraprasta PGRI

Jakarta, Indonesia

\begin{abstract}
This study aims to identify and provide a description of the development of the main character in the film Gifted Hands: The Ben Carson Story by Thomas Carter based on the approach of textual literary psychology through qualitative descriptive techniques, namely listening, observing, and copy-writing. Erikson's theory of psychological development, which reviews the development of the character influenced by those who are nearby becoming the focal point of the discussion - in terms of dialogue, action-reaction, and the situation depicted in the film. The findings in this study are four stages of character development from eight stages, namely school age, adolescence, early adulthood, and adulthood, at each stage, there are two elements namely dystonic (disruptive) and syntonic (harmony).
\end{abstract}

Keywords: character development, film analysis, characterization through dialogue, literary psychology

\section{INTRODUCTION}

Literature is the work of ideas, thoughts, feelings, experiences, and imagination expressed by a person in the form of writing, consisting of beautiful words that are arranged systematically through a creative process. Through literary works, readers or literary connoisseurs can find out about the values of life, social conditions, and society and everything that happens in it that can be an inspiration and motivation in the lives of the audience. This literary work in the form of novels, poetry, and drama. Unlike novels and poetry in which the readers must imagine the images of the characters, facial expressions, atmosphere, and the environment through words; drama has two forms, namely writing in the form of drama script - and stage - drama script that is manifested on the stage or moving images.

A moving picture or film is considered to be a representation of a literary work that presents a description of a character, environment, and situation in a novel/drama script in the original form. Therefore, the audience gets the same impression when seeing all these elements compared to when they read the novel/play script (Sikov, 2010, pp. 1-3).

Literary psychology is one of the literary research models used by someone in analyzing psychological factors of a literary work both the psychological factor of the author during the creative process of creating a literary work, readers or connoisseurs of literary works after reading the literary work, as well as the character of the characters figures contained in a literary work (Minderop, 2010, p. 59).

The psychological approach is needed to get to know someone's character besides psychology and literature have a close relationship because both have the same object, namely human life. Therefore, the essence of the analysis of literary works with a psychological approach needs to be conveyed through the characterization method so that it does not merely become a psychological study. Endraswara (2008) revealed that literary psychology is a literary study that views the work as a psychiatric activity, which means that a literary work is closely related to the 
psychological state of the author, reader, and the environment in which the author lives or the environment in which the author describes his story (p. 96 ).

Ratnasari (2012) analyzed the personality development of the main character named Emed from childhood to adulthood in the Babalik novel by Samsoedi. The theory used is Erikson's developmental theory. Wardani (2018) examines the psychology of the character of the main character in the novel Rindu, who has a background in the conditions of the Dutch ship in Blitar. The main character in this novel shows much religious value as an expression of identity to his readers. Besides, recognizing the main character's personality type, level of collective awareness and unconsciousness, and behavior of a woman's character who experiences a mental burden due to her father's crime (Septiarini \& Sembiring, 2017) can serve as a reflection of real life. Tracey (2010) examined the main character in the book Gifted Hands: The Ben Carson Story (henceforth GHTBCS) but in the context of the way the main character studied surgery. This study is not a literary study even though Tracey used the main character as the source of her studies, but her main focus was the way the main character was to study self-taught surgery. By knowing how to learn the main character, his study discovers surgical learning and teaching methods for medical students. The research mentioned above is proof that character analysis in work can help us to get an understanding or understanding of a thing or many things. That understanding can be found through a choice approach suitable for the purpose of the present study.

By using a literary psychology approach, the writer can analyze the character of the main character in the film GHTBCS (Carter, 2009). This real biographical film tells that every time Ben lived always had difficulties. However, the support of the closest people was the main factor for him to get up until finally, he became a pediatric neurosurgeon at John Hopkins Hospital. He also became the first doctor who successfully carried out the operation of conjoined twin separation operations in 1987 without resulting in one of the twins dying. He is known and successful. Therefore the development of one's personality is very much determined by the people and the environment around them.
In this study, the authors analyze personality development that emphasizes the ego quality of the main character, namely Ben Carson in the film based on the eight-stage theory of psychosocial development according to Erikson (Erikson \& Erikson, 1998). The stages include the stage of infancy, toddlers, preschool, school stage, adolescence, early adulthood, middle adulthood, and late adulthood.

\section{METHODS}

The research approach used by the authors in this study is a qualitative approach, which is a research approach without using statistical figures but is descriptive. This study describes an event or event that is related to the focus of the research and then describes it as it is. An objective and intrinsic approach are also used to examine the main character (Nurgiyantoro, 2014, p. 59).

Analyzing films is not the same as analyzing literary works in the form of writing because the pictures, movements, and sounds that appear in films affect the way of analysis. The combination of these three things makes us shift to visual analysis (Van Leeuwen \& Jewitt, 2011). This image, motion, and sound become an element that determines a perception from film analysis. In analyzing novels, for example, characters described in words will get interpretations and descriptions from some people who read them. The interpretation is different because each reader has different views, imaginations, and assumptions about a character or a situation. This difference is due to many factors, such as personal experience, known information, reader knowledge, mood, concentration, emotions, and even the cognitive abilities of these readers.

The results of the analysis are summarized in a table that accounts for eight stages of development according to Erikson's theory as follows: School Stage (US), Adolescence (Ad), Early Adulthood (DA), and Adulthood (Dw).

The researchers use a textual approach to find out the character of the main character. In the study of textual literature, it cannot be separated from Freud's psychoanalytic theory (Endarswara, 2013, p. 98). However, this study continues to develop, along with developments in the world of psychology itself. For this research, the writer will examine the main 
character's attitudes using Erikson's contemporary psychoanalytic theory (Erikson \& Erikson, 1998). Erikson's theory also focuses on the ego rather than the id and the superego, which is central to Freud's theory. The ego is adaptive and creative (Alwisol, 2017, pp. 9394).

\section{Erikson's Theory of Psychosocial Development}

There are six central tenets of Erikson's psychosocial development theory (Erikson, 1994):

a) The epigenetic principle, a term borrowed from embryology, refers to the character development at a particular stage (Hall \& Lindzey, 1993, p. 141).

b) Conflicting interactions, at every stage, are a psychosocial conflict between elements of syntonic (harmony) and dystonic (disruptive). These two elements are needed for personality development to be able to find a balance between the two who are more inclined towards syntonic.

c) The power of the ego, psychosocial conflicts that occur will affect the development of the ego. Sintonik's victory will produce a good quality ego called virtue, which has the role of increasing the quality of the ego to overcome similar conflicts; virtue is also referred to as basic strength.

d) Somatic aspects are related to the biological aspects of human development.

e) The multiplicity of conflict and event, which is the ego's identity is formed from conflicts and events that occurred in the past, present, and future.

f) In every development, especially starting from the period of adolescence and onwards, personality development is characterized by an identity crisis.

\section{Eight Stages of Psychosocial Development}

Alwisol (2017, pp. 99-113; Erikson \& Erikson, 1998, pp. 56-57) revealed that Erikson divided the stages of personality development into eight, namely:

1) The infancy stage (0-1-year-old): Trust versus Mistrust-the Hope Stage. In this stage, the baby experiences a psychosocial crisis called trust or suspicion. Early in life, infants spend their time eating, sleeping, and pooping. When the mother gives him food or drink, takes him to sleep, and cleans his feces, it is at this time that the baby obtains the quality of his first ego, namely basic trust. However, the discrepancy between the needs and the environment will enable the infant to develop a sense of basic mistrust. The ability to balance trust and mistrust can be the basis of people's ability to adapt.

2) Toddler stage (1-3 years old): Autonomy versus Shame-Doubt-Will Stage. At this stage, toddlers get satisfaction to be able to control bodily functions such as walking, holding, urinating, and so on. All of this is done through interpersonal relationships, which can also cause children to feel doubtful and embarrassed if their attempts to become autonomous are unsuccessful. At this time, children are faced with a culture that inhibits self-expression. Children learn several things at this time, including (i) The existence of rights and obligations; (ii) Limits on behavior; (ii) self-control; (iv) Receiving control from others. The success of a child in controlling his body will cause a sense of autonomy-pride, but on the contrary, if it fails, then he will feel shy. The ego identity that results from these two feelings is autonomy, shame, and doubt. If, in the previous stage, the child has a robust basic trust, then at this stage, he will become a confident kid, but if the opposite happens, then the child will be afraid to act for fear of failure and embarrassed when he makes a mistake.

3) Preschool stage (3-6 years old): Initiative versus Guilt-Purpose Stage. At this stage, the child has more space than the previous stage. Initiatives are used to choose and achieve various goals, if in the previous stage the child already knows things that are prohibited, however, the ambition of the child at this stage is not limited, so he be aggressive and manipulative to achieve his goals. Disallowed purposes will cause a sense of sin. The conflict between initiative and feelings of sin becomes the dominant psychosocial crisis at the preschool age. These two qualities must be balanced and be more inclined to the quality of the initiative. If only the initiative develops, chaos will occur, and moral principles diminish, but if the quality of guilt develops solely, it will result in confined morality. 
4) School-age (6-12 years old): Perseverance versus Inferiority-Competency Stage. At this age, a child will experience a psychosocial crisis between feelings of perseverance and inferiority. Perseverance is a diligent attitude in carrying out an activity until it is complete or until it reaches its goal. An inferior feeling will arise if all his efforts to achieve the goal are not successful.

5) Adolescence (12-20 years old): Identity and Identity Confusion-Fidelity Stage. The search for ego identity reaches its peak at this stage when teenagers look for their identity. According to Erikson, identity emerged from two sources, as follows:

a. Affirmation or deletion of identification in childhood.

b. History related to willingness to accept certain standards.

At this age, children have turned into adolescents, generally reject the standards of older people, and prefer the standards that apply among their friends. Nevertheless, some indeed still listen to their parents' words; parents' dictation continues because they tend to obey it (Marcia, 1966). Society and the environment are very influential in the formation of adolescent identity. Agustiani (2009, p. 35) also stressed that, at this time, teenagers need special recognition from their environment that he is unique and special. A positive identity is a decision taken by adolescents for their future. What they believe in; instead, a negative identity is a decision made, but not their desire and the beliefs they reject.

Adolescent often rejects the values of parents, but they also do not recognize the value of their group or peers, this dilemma will strengthen identity confusion. The emergence of problems that are present simultaneously, including sharing of selfimage (Mutamminah, 2014; Noviandari, 2017), inability to foster friendships, the lack of time management which makes it difficult for them to concentrate on carrying out tasks, rejection of values that prevail in the family and community (Setianingsih, Uyun, \& Zuwono, 2006).

This situation does not mean to be avoided by adolescents, but they must experience it to a certain degree; before later, finally, he obtained a stable identity. However, it is not good if too much identity disorder occurs, which will result in regression to past developments, and this will have an impact on personality development at a later stage. However, the balance between identity and identity disorder that tends to be favorable to identity will lead to:

a. Loyalty to certain ideological principles.

b. The freedom to decide what to do.

c. Trust among their peers and adults who advise about goals and ideals.

d. Job Choices.

6) Early Adulthood (20-30 years old): Intimacy versus Isolation-The Love Stage. At this stage, the experience of searching for identity during adolescence time is needed, an understanding of who he is at the time of adolescence will make it easier to unite himself with the identity of others. A person who has reached adulthood and begins to unite his identity and of others without fear of losing his identity is called intimacy. Intimacy can only be created if someone has formed a stable ego. However, at this stage, it is not real intimacy because, at this time, someone is looking for intimacy through sexual relations that accentuates extraordinary intimacy. Unlike the case with mature intimacy, it can be seen from its ability to share mutual trust that involves sacrifice, compromise, and commitment. Another ego quality at this time is isolation. It is the opposite of intimacy that is the inability to cooperate with others. If this quality predominates, it will lead to loneliness.

7) Middle Adulthood (30-65 years old): Generativity versus Stagnation - Care Stage. This stage of development is the longest because it takes approximately 30 years. It includes when a person places himself in the community and takes responsibility in every incident that happens in the community. Syntonic quality in adulthood is generative, which is related to the development of the younger generation and work in producing something that can benefit the community to be able to develop for the better. At this time, in addition to learning, he also wants to teach, this quality grows based on previous syntonic qualities such as intimacy and identity. Syntonic 
identity enables him to be able to understand himself, so he can interact and unite with other identities that give rise to another syntonic quality, intimacy. If in the early adult stages, this intimacy occurs with a partner, then at this adult stage, the intimacy occurs with the child. It is teaching children about culture to create community sustainability. The opposite of generativity is stagnation. This dystonic quality will emerge if someone is too self-centered, which causes no cultural development in society. However, this quality is also needed so that people can absorb the results of other people's creativity, as material to build better their syntonic qualities.

8) Late Adulthood ( $>65$ years old): Integrity vs. Despair-The Wisdom Stage. Late adulthood is not to make one not degenerated. Even though they can no longer have children, they can still be productive and creative in caring for their future generations (grandchildren). At this time, a person can have time to play and be happy because he is not busy with work problems anymore (retired), but this can also make him senile, depressed, and hopeless. At this stage, generally, the dominant quality is dystonic one (despair). There are only a few people who can have a psychological balance. People who can have this syntonic balance may possess a strong ego identity, which, in the previous stage, has made intimacy and showed concern for the environment and society. Syntonic quality of integrity is a feeling of being intact, its ability to unite feelings of self, and reducing physical and intellectual strength. The ego integrity will be challenging to maintain if someone has experienced the loss of something very close to him, such as the loss of his partner, health deterioration, physical weakening, mental robustness, independence, and loss of a social role in the society. These conditions can make him despair and manifest in the form of hatred, depression, insults, and other negative attitudes.

We may conclude that the development of the ego in each individual is strongly influenced by his/her social environment and background. The development takes place following the epigenetic principle, which means that the development of the ego takes place since the baby is born and continues throughout his life. In each stage of life, an individual can have values embedded throughout his life because they are related to each other. In other words, one does not go onto the next stage of development without the impacts of the former one.

\section{DISCUSSION}

This study found sixty-six datasets and four stages out of eight stages of Erikson's character development. For this paper, there are three to four findings that are most representative from each of the four stages of development. The discussion of the findings will include a dialogue quotation from the film GHTBCS followed by explanations according to Erikson's theory.

Further, Stage 1 to Stage 3 of the psychosocial development is not presented because there is no description, discussion, or the slightest trace of Ben's childhood in the film. As a result, the study will only present the discussion on Stage 4 to Stage 7.

\section{Settings}

GHTBCS is a biography of Ben Carson that tells a real character and a set of events that are also real. Even though the characters and events are real, several stories are not told clearly. Some important locations such as Ben's old residence and institutions, as well as the hospital where he collaborated with real events. The effort to present locations and real events is an attempt to give a picture as clear and as close as possible to its history. One location that is similar to a real event is John Hopkins Hospital in Maryland, United States.

The situation described is the situation from the 1970 s to the 1980 s. It is clearly illustrated through the costumes (clothing, clothing colors), vehicles (brand and type of car), house models, and equipment displayed through the location of the house, hospital, and the highways depicted in the film. It turns out that a picture like this can make the audience as they can see the main character in a particular location and situation.

\section{Characters}

The discussion in this section is limited to the main character and other supporting figures who play an essential role in Ben's psychosocial development in the film: 
a. Ben Carson is the main character in this film. It is the center of the whole story, mainly because the biographical film must properly make the attention of the audience focused on the development process of this character - live emotions, thoughts, and actions.

b. Other supporting figures who played an essential role in the four stages of Ben's development include Sonya Carson Ben's mother and Candy - Ben's wife.

\section{Plot}

The chronological plot is used in this biographical film through which the director can make the audience watch and feel the process experienced by Ben and got lost in emotion and finally develop a positive perspective on him. Although the reversal plot can be presented in a biographical film, in this film, the chronological plot makes it easier to analyze the development of the main character's attitudes.

\section{Themes}

The theme highlighted in this GHTBCS is the success resulted from tireless effort or hard work, perseverance, and love. There are many moral values learned from following the process of attitudes development of the main character - who is considered stupid, born from a low-income family, have no experience in the college education- who then made history in the medical world.

\section{Psychosocial Development Stage of the Main Character \\ Stage 4 - Competence (School Age)}

We found that the role of adults both the parents and other the teacher has a vital role in the development of a child's character.

(a) Ben is an unconfident kid. He felt stupid because he could not do all the quiz questions given by his teacher.

Mrs. Williamson: "Benjamin? Benjamin, how many did you get right?"

Ben: "None"

Mrs. Williamson: "None?" Benjamin, that's wonderful! I'm so proud of you!"

Kathy: "Not nine, Mrs. Williamson. He got NONE!"

[Situation: laughed by all the classmates] (00:007:41 - 00:08:02)
Ben was sitting in the fifth grade. When his class teacher held a quiz on mathematics, none of the questions given he could answer correctly. This incident broke his heart and has impacted on Ben's psyche later. Failure in class seemed to give Ben proof that he had no potential for success.

Another evidence is that his teacher did not offer any help to Ben, as if he didn't deserve it. Therefore, at the next stage of development in the film, Ben feels inferior on many occasions in his life.

(b) Ben's friends always make fun of him to make him even more insecure.

Kathy: "You'd think he'd get at least one right."

Mark: "He got one right last time 'cause he was trying to put down the wrong answer." [Other students laugh]

Mark: "Hey, Carson, we know you're the dumbest kid in the class, but did you hear what they say on Cronkite last night on the news? You're the dumbest kid in the world." (00:08:11 - 00:08:25)

During the break, Mark made fun of Ben by saying that one of the news television stations reported that Ben was the dumbest kid in the world, and this made Ben lose his selfconfidence and feel inferior.

(c) His mother always motivates Ben and tries to restore his confidence.

Sonya: "So what happened? You weren't getting grades like that in Boston?"

Ben: "Boston was easier. They don't ask us to do much."

Sonya: "Well, I ain't asking you either, I'm telling you. You weren't meant to be a failure; Bennie and you can control your temper." (00:09:12 - 00:09:22)

Ben: "He called me a dummy."

Sonya: "You're a smart boy. Listen to me! Listen to me! You just ain't using that smartness." (00:09:03 - 00:09:12)

Because of being mocked by his friend, Ben lost control and hit them so that the principal called him and his mother. Ben felt that he was unable to attend the school, he always failed because of his poor grades, and his friends always thought him stupid. However, his mother always motivated and convinced him that he could catch up with the lessons, succeed and that he was not a temperamental child.

The syntonic quality of perseverance that Ben shows is due to the enormous influence of his mother, Sonya, who always encourages and gives him confidence. Ben 
began to dare to have ideals and feel able to achieve it. Although ben missed the role of the father in this period, his perseverance began to develop when Ben's mother tried to replace the role of the father in the family.

\section{Stage 5 - Loyalty (Adolescence)}

Someone, at this stage, is prone to get affected by bad attitudes of the environment as he/she aspires to be recognized in the community. However, if he has a keen awareness and desire to achieve his goals and closest people who can advise him correctly, he will become successful and achieve his goals.

(a) Ben was entitled to the highest academic achievement when he was the eighthgrader in his school.

The Principal: "The certificate for the student with the highest academic achievement in the eight grade goes to Benjamin Carson." Ben: (Receiving the award) (00:33:10 00:33:22)

Ben's achievement is getting better until he was awarded as a student with the highest academic achievement in his school. It finally increases his enthusiasm to learn and achieve his goals because he received recognition from not only his friends, but also the recognition of the whole school members.

(b) Moving from Detroit back to Boston

Sonya: "We're moving."

Ben: "We're moving?"

Sonya: "That speech your eighth-grade teacher gave, tacked me off, so I went to the bank.

I've finally saved enough money to take back that house we've been renting out. So, starting next fall, you're going to school that appreciates you." (00:35:38 - 00:35:56)

When receiving the award, his class teacher gave a racist speech. It was the reason that urged his mother to take him back to and moved to Boston. This move raises new hopes for Ben to be more acceptable and recognized by his new environment.

(c) Getting a scholarship and studying at Yale University in medical school with a specialization in neurosurgery.

Yale Professor: "It's in my opinion, the most amazing organ the human body holds.

By stimulating one section of the brain of an 85year-old, you can bring back, verbatim, memories of a newspaper article read 60 years before. Consider your own brains, they've absorbed and digested enough information to bring you here which is not small achievement. Your dreams are all possible because of three pounds gray matters. We can describe it physically, but it won't give clue as to how it does what it does which is why I devoted my life as a surgeon to probing its mysteries."

Ben: "How did you do that?

Yale Professor: "A lot of time away from home, my wife will tell you." (00:44:08 - 00:44:50)

At the age of 18, Ben got a scholarship to study at Yale University, faculty of medicine. Since Ben was in elementary school, he had aspired to become a doctor. Although suffering an identity crisis in high school, Ben was still able to overcome it all because of the intense teaching of religious values by his mother. Thus he could find his identity and maintain his ambition to become a doctor.

(d) Candy, Ben's girlfriend, always encourages and helps him in learning so that Ben can pass the Chemistry test with an A.

Candy: "What are you good at when it comes to studying, what works best for you?"

Ben: "I don't know. Reading. I'm good at reading. If all I ever did was read, I'd be just fine. Instead, I got to sit all these boring lectures eight

hours a day. (00:46:15 - 00:46:25)

Ben was almost desperate because he could not take the Chemistry course, and was very worried about losing his scholarship if he failed the exam. The presence of Candy is significant for Ben because she always helps and encourages him to keep focused on pursuing his dream.

At this stage, Ben shows his anger and demanding attitude. To be accepted in his social environment, Ben often opposed his mother and even threatened his mother. However, an incident made him realize and regret all his mistakes, and this was his turning point. All this happened because of a solid religious education given by his mother.

\section{Stage 6 - Love (Early Adulthood)}

In his adolescence, Ben experienced an identity confusion, while then at this stage, he will experience a sense of isolation because he is unable to mingle with others. Conversely, if he figured out the identity at the adolescence time, he would be able to understand himself and recognize his goals so that he can blend with others and share.

(a) Ben applied to become an intern at John Hopkins Hospital

Dr. Udvarhelyi: "You have confidence.

Yes, that's good in a neurosurgeon. 
But tell me something. Why did you decide to become aresponsibility, humanity, and encouragement brain doctor?"

Ben: "The brain....it's a miracle..."

(00:51:01 - 00:51:26)

Ben applied to become an intern at John Hopkins Hospital in Maryland, Baltimore. He has made up his mind to become a neurosurgeon. His professor at the university questioned Ben's choice. In general, people answer job interview questions as posed by the professor with scientific reasons, are academic, or want to achieve a certain achievement. While Ben expressed his admiration for the brain, "The brain ... it's a miracle". The curiosity and attractiveness of Ben's choice to become a brain surgeon is proof that others can see the sign of the stability of choice for a job and Ben's interests when he is in his early adulthood. Ben also replied that he was amazed by the way the brain works, and neurology has helped him understand and make him more impressed with the brain organs. The first day at John Hopkins Hospital

Dr. Hairston: "Carson draw some blood!"

Ben: "Doctor, according to his charts, he may be anemic. I don't think ..."

Dr. Hairston: "Well, I don't care what you think. You do as I say. Don't think you're special, Carson. Simple 'cause there's no one like you in this department. If you don't change your attitude, I'll get you kicked out of neurosurgery faster than you can say 'Yassuh'." (00:53:28 - 00:53:55)

On the first day as an intern doctor at John Hopkins Hospital, Ben had to deal with a very rigid and unhappy hospital atmosphere. When he went around with fellow interns and an expert doctor, he experienced unexpected incidents. However, it did not make him inferior because he is intimate to interact with others and knows what he must do.

(b) Ben was forced to undergo a lobectomy without the supervision of an experienced doctor.

Nurse Smith: "I can't reach Dr. Farmington and I can't reach Dr. Udvarhely."

Ben: "If someone doesn't operate on this man, soon he will die."

Nurse Smith: "Go for it!"

Ben: "I'm not qualified to do a lobectomy."

(00:55:48 - 00:56:06)

Once there was an emergency when a patient needed to be operated immediately. However, no other more competent doctor could do it at the Emergency Unit, where Ben became an intern. However, due to a great sense of from Sister Smith, she operated even though it could jeopardize not only her career as a doctor but also the reputation of the hospital.

The main character, Ben, at this stage, begins to have a lover who always supports and helps him in learning, even when he is almost desperate because he feels that he will not pass the chemistry course. It is his girlfriend who encourages him and helps him study, so he graduated with an outstanding grade.

\section{Stage 7 - Caring (Adulthood)}

This stage, a person not only unites or adapts to the identity of others but also cares about others and starts teaching others (the next generation) about everything that he knows. At this stage, also a person starts productive to create something not for himself but for the world or environment to be better. All of that is called generative syntonic quality. Conversely, if someone is selfish, who is only selfish, this is what makes him unproductive and become stagnant (dystonic).

(a) Ben performed surgery and succeeded in a 4-year-old boy who was diagnosed with Rasmussen's Encephalitis.

Pediatric Patient's Mother: "How is she?"

Ben: "It took twice as long as we thought,

she lost nine pints of blood which is

double her normal volume, but she came

through just fine." (00:04:24 - 01:04:34)

One day, a 4-year-old child who was experiencing seizures suddenly came to the emergency room. This child is suffering from a neurological disease called Rasmussen's Encephalitis, which causes seizures, loss of motor skills, and speech. To cure him, Ben had to operate on him and take a portion of the child's left brain. Moreover, his success is one of his successes.

(b) Ben and Candy lost their twin babies.

Candy: "Shouldn't you be on duty?"

Ben: "I am."

Candy: "I mean neurosurgery.

Your patients need you."

Ben: "You need me."

Candy: "I have you. Go to work!"

(01:08:49 - 01:09:08)

Candy miscarried when this dialogue occurred. They had to lose twins, and this was a big blow to Ben, almost frustrating him, but Candy reminded him that he still had to keep working and caring for his patients because they needed Ben more. The main character, Ben, at this 
stage, has a profound concern and always wants to do something for his patients. However, at the same time, he showed care and affection for Candy by choosing to stay at home. Not burying himself in work. Both of these figures show the maturity of mature emotions.

Ben, the main character in the film by Thomas Carter, at each stage of its development, the dominant element found is the syntonic (harmony) element. Thus, it can be said that Ben experienced an outstanding character development, and this happened because he was surrounded by people who helped him to always develop into a better and more mature person.

\section{CONCLUSION}

Ben's character develops into a strong character. He is always caring and has a strong determination to work. It owes to his mother's massive role in every development. Besides his mother, his wife also has a vital role in the development of Ben's character. Every time Ben went downhill, he always had other people around him who were always there to make him rise.

Sense of inferiority or inadequacy that grows during school age can be transformed into perseverance because of the unceasing encouragement and support from the mother, who always motivates him to become someone who has self-confidence. His mother was a figure who never gave up. It is precisely what she always taught to Ben. When Ben grew up, he had not only his mother but also a wife who always supported all his work. Apart from the family, he has colleagues who are ready to help and support all his actions.

\section{REFERENCES}

Agustiani, H. (2009). Psikologi perkembangan pendekatan ekologi kaitannya dengan konsep diri dan penyesuaian diri pada remaja. Bandung: PT. Refika Aditama.

Alwisol. (2017). Psikologi Kepribadian. Malang: Universitas Muhammadiyah Malang.

Carter, T. (2009). Gifted Hands: The Ben Carson Story. United States: Sony Pictures Television. Retrieved from https://en.wikipedia.org/wiki/Gifted_Hands:_The_Ben_Carson_Story

Endraswara, S. (2008). Metodologi Penelitian Sastra (2nd ed.). Yogyakarta: Pustaka Widyatama.

Erikson, E. H. (1994). Identity and the Life Cycle (3rd ed.). New York: W. W. Norton \& Company. Retrieved from https://books.google.co.id/books?id=mNTECQAAQBAJ

Erikson, E. H., \& Erikson, J. M. (1998). The Life Cycle Completed (Extended Version) (2nd ed.). New York: W. W. Norton \& Company. Retrieved from https://books.google.co.id/books?id=SKidSuluprgC

Hall, C. S., \& Lindzey, G. (1993). Teori-teori Psikodinamik (Klinis). Yogyakarta: Kanisius. Retrieved from https://books.google.co.id/books?id=DaAOiNyvWF0C

Marcia, J. E. (1966). Development and validation of ego-identity status. Journal of Personality and Social Psychology, 3(5), 551-558. https://doi.org/10.1037/h0023281

Minderop, A. (2010). Psikologi Sastra: Karya Sastra, Metode, Teori, dan Contoh Kasus (1st ed.). Jakarta: Yayasan Pustaka Obor Indonesia.

Mutamminah, M. (2014). Hubungan Konsep Diri dan Kecerdasan Emosi dengan Kemampuan Penyesuaian Diri pada Remaja. Persona:Jurnal Psikologi Indonesia, 3(1), 42-51. https://doi.org/10.30996/persona.v3i01.368

Noviandari, H. (2017). Keterkaitan konsep diri, problem solving, dan penyesuaian diri pada remaja. 
Jurnal Ilmiah Psikologi Terapan. https://doi.org/10.22219/jipt.v5i2.4559

Nurgiyantoro, B. (2014). Teori Pengkajian Fiksi. Yogyakarta: Universitas Gadjah Mada Press.

Ratnasari, M. (2012). Perkembangan Kepribadian pada Tokoh Utama dalam Novelete 'Babalik' Pikir karya Samsoedi. Jurnal Unpad, 1(1), 13. Retrieved from http://jurnal.unpad.ac.id/ejournal/article/view/1779

Septiarini, T., \& Sembiring, R. H. (2017). Kepribadian Tokoh dalam Novel “Mencari Perempuan yang Hilang” (Kajian Psikoanalisis Carl Gustav Jung). LiNGUA: Jurnal Ilmu Bahasa Dan Sastra, 12(2), 79. https://doi.org/10.18860/ling.v12i2.4279

Setianingsih, E., Uyun, Z., \& Zuwono, S. (2006). Hubungan antara penyesuaian sosial dan kemampuan menyelesaikan masalah dengan kecenderungan perilaku delinkuen pada remaja. Jurnal Psikologi Universitas Diponegoro, 3(1), 29-35. Retrieved from https://ejournal.undip.ac.id/index.php/psikologi/article/viewFile/689/552

Sikov, E. (2010). Film Studies: An Introduction. New York: Columbia University Press. Retrieved from https://books.google.co.id/books?id=zbCK8ETCWzwC.

The Johns Hopkins University, The Johns Hopkins Hospital, and J. H. H. S. (n.d.). Benjamin Solomon Carson, Sr., M.D. Retrieved August 13, 2019, from https://www.hopkinsmedicine.org/stlm/carson.html\#.XVJ4qwxXvLc.link

Tracey, K. J. (2010). Gifted hands. Journal of Clinical Investigation, 120(6), 1790-1790. https://doi.org/10.1172/JCI43074

Van Leeuwen, T., \& Jewitt, C. (2011). Introduction. In The Handbook of Visual Analysis (pp. 2-9). 1 Oliver's Yard, 55 City Road, London England EC1Y 1SP United Kingdom: SAGE Publications Ltd. https://doi.org/10.4135/9780857020062.n1

Wardani, Y.F. (2018). Nilai pendidikan karakter dalam novel 'Rindu' karangan Tere Liye: Tinjauan psikologi karakter. Jurnal Pendidikan Bahasa dan Sastra Indonesia (AKSIS), Vol. 2 (2). Diakses dari http://journal.unj.ac.id/unj/index.php/aksis/article/view/9550. 